\title{
PENGARUH MOTIVASI, REMUNERASI DAN KEPEMIMPINAN TERHADAP KINERJA PERSONIL PADA SAT SABHARA POLRES OKU TIMUR
}

\author{
Dyah Ayu Putriani \\ Dosen Universitas Baturaja \\ dyahayujuvedona@gmail.com
}

\begin{abstract}
The population in this study amounted to 50 personnel. Based on the results of data analysis using multiple linear regression values obtained for Motivation (X1) with Personnel Performance $(Y)$ tcount $>$ table is 2.860> 2.01290 and a significant level of $0.006<0.05$ means there is an influence between Motivation (X1) and Performance Personnel (Y). For Remuneration (X2) with Personnel Performance (Y) tcount $>$ ttable is $5.403>2.01290$ and a significant level of $0.000<0.05$ means there is an influence between Remuneration $(X 2)$ and Personnel Performance (Y). As for Leadership (X3) with Personnel Performance (Y) tcount $>$ ttable is $2.147>2.01290$ and a significant level of $0.037<0.05$ means there is an influence between Leadership and Personnel Performance. While simultaneous testing (together) Motivation (X1), Remuneration (X2) and Leadership (X3) affect the Performance of Personnel (Y) with a value of Fcount $>$ Ftable that is $50.546>2.81$. Then the coefficient of determination (Adjusted $R$ Square) of 0.752 shows that the influence of the variables Motivation (X1), Remuneration (X2) and Leadership (X3) on Personnel Performance (Y) at the OKU East Police Sabhara Unit is $75.2 \%$ while the rest is influenced by other variables not included in this study.
\end{abstract}

\section{Keywords: Motivation, Remuneration, Leadership and Personnel Performance}

\section{PENDAHULUAN}

\section{Latar Belakang}

Manajemen sumber daya manusia adalah ilmu dan seni mengatur hubungan dan peranan tenaga kerja agar efektif dan efisien membantu terwujudnya tujuan perusahaan, karyawan, dan masyarakat (Hasibuan, 2017:10). Sumber daya manusia harus menjadi manusia-manusia pembelajar, yaitu pribadi yang mau belajar dan bekerja keras dengan penuh semangat, sehingga potensi insaninya berkembang maksimal karena tekhnologi saja tidak akan cukup jika tidak ditunjang oleh sumber daya manusia yang andal. Adanya sumber daya manusia yang terdidik, terampil, berdisiplin, tekun dan mau bekerja keras ternyata berhasil meraih kemajuan yang sangat besar. Oleh karena itu, pengelolaan sumber daya manusia yang baik merupakan kunci sukses tercapainya tujuan organisasi guna memajukan kesejahteraan suatu bangsa. Sumber daya manusia merupakan asset yang harus ditingkatkan secara efektif dan efisien sehingga terwujud kinerja yang optimal.

Dengan menganalisis efisiensi penggunaan modal kerja maka dapat diketahui bagaimana kebijaksanaan yang akan diambil oleh perusahaan dalam usahanya mengoperasikan modal yang ada sehingga dapat diketahui tingkat efisiensi dari modal yang dioperasikan, oleh karena itu peran modal kerja itu sangat penting dalam proses atau jalannya suatu usaha, maka diperlukan manajemen modal kerja yang baik, Modal kerja adalah investasi 
perusahaan dalam harta jangka pendek seperti: kas, surat berharga jangka pendek, piutang dan persediaan.

Manajemen sumber daya manusia diorientasikan pada peningkatan kinerja. Kinerja merupakan satu hal yang tidak dapat dipisahkan dengan perusahaan. Kinerja karyawan merupakan hasil kerja secara kualitas dan kuantitas yang dicapai oleh seseorang karyawan dalam melaksanakan tugasnya sesuai dengan tanggung jawab yang diberikan kepadanya (Mangkunegara, 2019:09). Dalam beberapa tahun ini, para pegawai sektor publik dari berbagai Instansi, Kementrian dan Lembaga pemerintahan lainnya sedang menikmati konsep remunerasi sebagai salah satu aspek dalam agenda reformasi birokrasi. Remunerasi tersebut bertujuan untuk memperbaiki mekanisme penghasilan dan pendapatan seorang pegawai dari berbagai level dan memperbaiki struktur dalam birokrasi dalam meningkatkan kinerja pegawai pemerintahan.

Untuk meningkatkan kinerja Polri, pemerintah telah menyetujui pemberian tunjangan kinerja atau remunerasi bagi pegawai dilingkungan Polri sesuai pada Peraturan Presiden Republik Indonesia Nomor 103 Tahun 2018 tentang tunjangan kinerja pegawai di lingkungan Kepolisian Negara Republik Indonesia.

Berdasarkan observasi awal yang telah peneliti lakukan yaitu adanya permasalahan mengenai motivasi, remunerasi, dan kepemimpinan yang ada pada Sat Sabhara Polres OKU Timur. Untuk melihat bagaimana kondisi sebenarnya mengenai kinerja personil maka peneliti melakukan pra-survey dengan menyebarkan kuesioner sementara, yang terdiri dari beberapa indikator mengenai motivasi kepada 25 personil. motivasi pada Sat Sabhara Polres OKU Timur secara keseluruhan belum sesuai dengan pencapaian yang diharapkan. Hal ini dikarenakan masih terdapat masalah yang terlihat di indikator motivasi, yaitu kebutuhan berprestasi dengan nilai rata-rata 3,52 yang paling terkecil diantara indikatorindikator lainnya. Maka dapat disimpulkan bahwa di Sat Sabhara Polres OKU Timur masih terdapat masalah yaitu kurangnya rasa tanggung jawab dalam bekerja dan cenderung lamban atau tidak dengan sungguh-sungguh dalam melaksanakan tugas yang sudah diberikan pimpinan. Hal ini dikarenakan, kurangnya dorongan dari dalam diri personil untuk bertanggung jawab terhadap pekerjaannya yang menimbulkan kebiasaan kerja yang buruk. Hal ini tentunya mempengaruhi kinerja yang dicapai personil Sat Sabhara Polres OKU Timur menjadi kurang efektif sebagaimana mestinya yang telah ditentukan. Motivasi merupakan kondisi atau energi yang menggerakkan diri karyawan yang terarah atau tertuju untuk mencapai tujuan organisasi perusahaan. Sikap mental karyawan yang pro dan positif terhadap situasi kerja itulah yang memperkuat motivasi kerjanya untuk mencapai kinerja maksimal (Mangkunegara, 2019:61).

Remunerasi masih terdapat masalah. Hal tersebut dapat dilihat dan dibuktikan dengan adanya hasil dari nilai rata-rata paling terkecil yang terdapat di indikator Adil yaitu sebesar 3,28. Permasalahan yang terdapat di indikator tersebut adalah mengenai remunerasi yang diterima saat ini kurang sesuai dengan beban kerja yang diemban dan harus dilaksanakan masingmasing personil. Hal ini dikarenakan, banyaknya pekerjaan yang harus dioptimalkan sedangkan untuk pembagian beban kerja atau tugas pelaksanaannya masih terdapat ketimpangan antar personil sebab jumlah personil Riil yang ada saat ini pada tingkat kepolisian resort tidak sesuai dengan seharusnya menurut daftar susunan personil Sat Sabhara berdasarkan Perkap Nomor 23 Tahun 2010 tentang susunan 
organisasi dan tata kerja pada tingkat kepolisian resort dan kepolisian sektor. Hal ini menyebabkan terjadinya kesenjangan antar personil dan tentu saja mempengaruhi kinerja personil yang berkaitan dengan jam kerja karena pemberian/pemotongan remunerasi berdasarkan tingkat kehadiran personil. Untuk pemberian/pemotongan remunerasi dilakukan oleh Bendahara satuan Polres OKU Timur yang berkerjasama dengan Seksi Profesi dan pengamanan (Si Propam Polres OKU Timur) yang melakukan perekapan absensi personil Sat Sabhara Polres OKU Timur pada setiap bulannya. Pemberian remunerasi merupakan suatu hal yang penting bagi personil karena merupakan bentuk balas jasa atau imbalan kerja diluar gaji yang dikaitkan dengan sistem penilaian kinerja atas kontribusi yang diberikan oleh personil. Menurut Kamus Besar Bahasa Indonesia (dalam Rahayu, 2017:10) remunerasi merupakan pemberian hadiah (penghargaan atas jasa atau lainnya).

Kepemimpinan yang ditunjukkan Kasat Sabhara masih belum mampu mendukung personil Sat sabhara dalam melaksanakan tugas secara optimal. Sebab, dirasakan Kasat Sabhara kurang mampu dalam membimbing dan mengarahkan personil. Sedangkan, kepemimpinan mempunyai peranan yang sangat penting dalam menggerakkan dan mengarahkan organisasi karena sukses tidaknya usaha dalam pencapaian tujuan organisasi ditentukan oleh kualitas kepemimpinan. Kepemimpinan adalah suatu proses kegiatan seseorang untuk menggerakkan personil lain dengan memimpin, membimbing, memengaruhi personil lain, untuk melakukan sesuatu agar dicapai hasil yang diharapkan (Sutrisno, 2019:213).

Berdasarkan hasil kuesioner sementara kepada personil Sat Sabhara Polres OKU Timur. Maka dari itu penulis tertarik untuk mengadakan penelitian lebih lanjut tentang "Pengaruh Motivasi, Remunerasi Dan Kepemimpinan Terhadap Kinerja Personil Pada Sat Sabhara Polres OKU Timur".

\section{TINJAUAN PUSTAKA Pengertian Manajemen Sumber Daya Manusia}

Manajemen sumber daya manusia merupakan proses pengelolaan manusia, melalui perencanaan, rekrutmen, seleksi, pelatihan, pengembangan, pemberian kompensasi, karier, keselamatan dan kesehatan serta menjaga hubungan industrial sampai pemutusan hubungan kerja guna mencapai tujuan perusahaan dan peningkatan kesejahteraan stakeholder (Kasmir, 2016:06). Menurut Schuler, et al. manajemen sumber daya manusia merupakan pengakuan tentang pentingnya tenaga kerja organisasi sebagai sumber daya manusia yang sangat penting dalam memberi kontribusi bagi tujuan-tujuan organisasi, dan menggunakan beberapa fungsi dan kegiatan untuk memastikan bahwa sumber daya manusia tersebut digunakan secara efektif dan adil bagi kepentingan individu, organisasi, dan masyarakat (Sutrisno, 2019:06).

\section{Motivasi}

Robbins menyatakan bahwa motivasi sebagai suatu kerelaan berusaha seoptimal mungkin dalam pencapaian tujuan organisasi yang dipengaruhi oleh kemampuan usaha memuaskan beberapa kebutuhan individu (Sutrisno, 2019:111). Menurut Bernard Berelson dan Gary A. Stainner mendefinisikan motivasi sebagai all those inner striving conditions variously described as wishes, desire, needs, drives, and the like artinya motivasi sebagai keadaan kejiwaan dan sikap mental manusia yang memberikan energi, mendorong kegiatan (moves), dan mengarahkan atau menyalurkan perilaku ke arah mencapai kebutuhan yang memberi 
kepuasan atau mengurangi ketidakseimbangan (Siswanto, 2007:119). Adapun, menurut Fillmore H. Stanford motivasi sebagai suatu kondisi yang menggerakkan manusia ke arah suatu tujuan tertentu (Mangkunegara, 2017:93).

\section{Remunerasi}

Menurut Sikula $A$ renumeration is a reward payment or reimbursement for services rendered artinya remunerasi adalah suatu hadiah, pembayaran, atau balas jasa untuk jasa yang diberikan (Hasibuan, 2017:119). Sedangkan, menurut Pora (dalam Fitriyana, Pangestika dan Anthon Rustono, 2016:1071) dalam konteks perusahaan, remunerasi diartikan sebagai suatu tindakan balas jasa/imbalan yang diterima karyawan/pekerja dari pengusaha atas prestasi yang diberikan pekerja dalam rangka mewujudkan perusahaan. Lebih lanjut dijelaskan bahwa tujuan pemberian remunerasi dalam konteks perusahaan adalah untuk memaksimumkan keuntungan atau memperoleh laba sebesar-besarnya dengan memanfaatkan biaya seefisien mungkin. Berdasarkan beberapa pendapat para ahli yang di kemukakan di atas, maka Remunerasi yaitu sebagai imbalan uang ataupun yang lainnya dan telah ditetapkan oleh peraturan tertentu sebagai imbalan kinerja yang sifatnya rutin.

\section{Kepemimpinan}

Kepemimpinan adalah cara seorang pemimpin mempengaruhi perilaku bawahan, agar mau bekerja sama dan bekerja secara produktif untuk mencapai tujuan organisasi (Hasibuan, 2017:170). Kepemimpinan juga dapat diartikan suatu proses kegiatan seseorang untuk menggerakkan personil lain dengan memimpin, membimbing, mempengaruhi personil lain, untuk melakukan sesuatu agar dicapai hasil yang diharapkan (Sutrisno, 2019:213). Selain itu, kepemimpinan merupakan sikap dan perilaku untuk mempengaruhi para bawahan agar mereka mampu bekerja sama sehingga membentuk jalinan kerja yang harmonis agar tercapai efisiensi dan efektivitas guna mencapai tingkat produktivitas sesuai dengan yang telah ditetapkan (Siswanto, 2007:169). Adapun, menurut Siagian kepemimpinan adalah kemampuan seseorang untuk memengaruhi personil lain, dalam hal ini para bawahannya sedemikian rupa sehingga personil lain itu mau melakukan kehendak pimpinan meskipun secara pribadi hal itu tidak mungkin disenanginya (Sutrisno, 2019:213). Sedangkan, menurut Anoraga kepemimpinan sebagai kemampuan seseorang untuk dapat mempengaruhi pihak lain, melalui komunikasi baik secara langsung maupun tidak langsung dengan maksud untuk menggerakkan personil-personil agar dengan penuh pengertian, kesadaran dan senang hati bersedia mengikuti kehendak-kehendak pemimpin itu (Sutrisno, 2019:214).

\section{Kinerja Karyawan}

Kinerja merupakan hasil kerja dan perilaku kerja yang telah dicapai dalam menyelesaikan tugas-tugas dan tanggung jawab yang diberikan dalam suatu periode tertentu (Kasmir, 2016:182). Sedangkan, menurut Robbins kinerja ialah sebagai fungsi dari interaksi antara kemampuan atau ability (A), motivasi (M), dan kesempatan atau opportunity $(\mathrm{O})$; yaitu kinerja $=\mathrm{f}(\mathrm{A} x$ $\mathrm{M} \times \mathrm{O})$, artinya kinerja merupakan fungsi dari kemampuan, motivasi dan efisiensi (Kasmir 2016:183). Selain itu, kinerja adalah hasil kerja secara kualitas dan kuantitas yang dicapai oleh seorang pegawai dalam melaksanakan tugasnya sesuai dengan tanggung jawab yang diberikan kepadanya (Mangkunegara, 2017:67).

\section{Penelitian Sebelumnya}

Arifudin (2017) tentang pengaruh kepemimpinan dan disiplin kerja terhadap kinerja karyawan PD BPR Bank Daerah Kabupaten Kediri. Penelitian ini menggunakan alat regresi linear berganda. Hasil penelitian diketahui bahwa secara 
bersama-sama seluruh variabel bebas kepemimpinan dan disiplin kerja berpengaruh signifikan terhadap variabel terikat kinerja karyawan. Secara parsial variabel kepemimpinan memiliki pengaruh signifikan terhadap kinerja karyawan. Sedangkan variabel disiplin kerja memiliki pengaruh signifikan terhadap kinerja karyawan.

\section{Kerangka Pemikiran}

\section{Gambar 1}

Kerangka Pemikiran

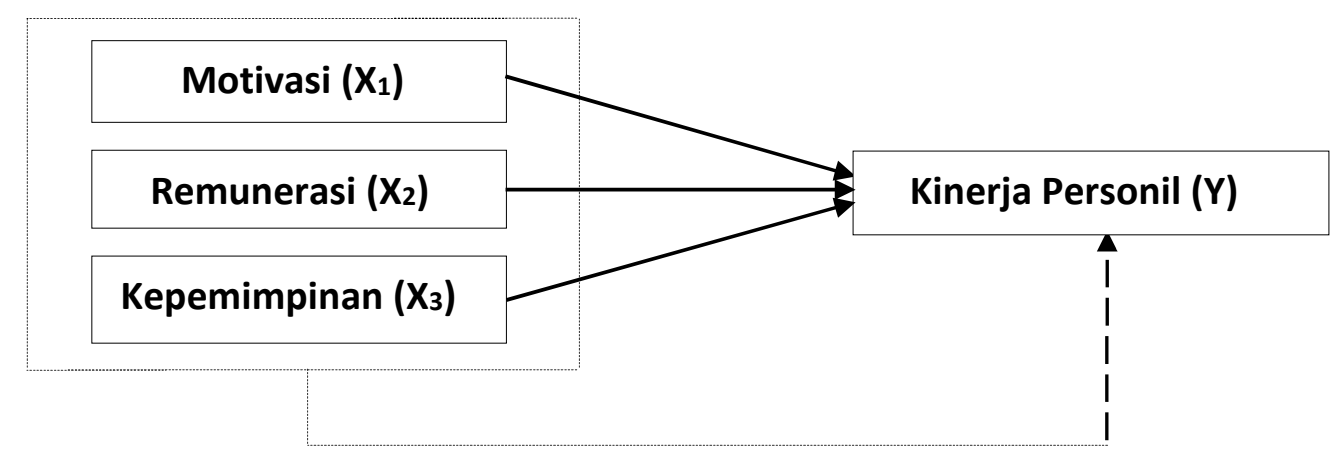

\section{Keterangan :}

\section{Secara Simultan \\ $\longrightarrow \quad$ Secara Parsial}

\section{METODOLOGI PENELITIAN Ruang Lingkup Penelitian}

Ruang lingkup pembahasan pada pengaruh Motivasi, Remunerasi dan Kepemimpinan berpengaruh Terhadap Kinerja Personil. Objek penelitian ini adalah seluruh personil Sat Sabhara Polres OKU Timur yang berjumlah 50 Personil.

\section{Jenis dan Sumber Data}

Dalam penelitian ini jenis data yang digunakan ialah data kuantitatif. Data kuantitaf dalah data yang berbentuk angka atau data kualitatif yang diangkakan/scoring (Sugiyono, 2016-28). Sumber data yang digunakan untuk pengumpulan data menggunakan data primer. Sumber primer adalah sumber data yang langsung memberikan data kepada pengumpul data (Sugiyono, 2016-223).

\section{Teknik pengumpulan data}

Teknik pengumpulan data yang digunakan dalam penelitian ini dokumentasi yaitu teknik penelitian dengan mengumpulkan dokumentasi seperti jurnal dan data-data lain dengan cara mencatat, menyalin dan mengunduh dokumen yang sesuai dengan data sekunder yag dibutuhkan dan kemudian diolah oleh peneliti. 


\section{Batasan Operasional Variabel \\ Batasan Operasional Variabel}

\begin{tabular}{|c|c|c|}
\hline Variabel & Definisi & Indikator \\
\hline $\begin{array}{l}\text { Motivasi } \\
\left(\mathrm{X}_{1}\right)\end{array}$ & $\begin{array}{l}\text { Sesuatu yang ada pada diri } \\
\text { seseorang yang dapat } \\
\text { mendorong, mengaktifkan, } \\
\text { menggerakkan dan mengarahkan } \\
\text { perilaku seseorang }\end{array}$ & $\begin{array}{l}\text { 1. Kebutuhan untuk berprestasi } \\
\text { (Need for Achievement) } \\
\text { 2. Kebutuhan untuk berafiliasi } \\
\text { (Need for Affiliation) } \\
\text { 3. Kebutuhan untuk kekuasaan } \\
\text { (Need for Power) } \\
\text { (Mangkunegara, 2017:97) }\end{array}$ \\
\hline $\begin{array}{l}\text { Remunerasi } \\
\left(\mathrm{X}_{2}\right)\end{array}$ & $\begin{array}{l}\text { Imbalan uang ataupun yang } \\
\text { lainnya, yang telah ditetapkan } \\
\text { oleh peraturan tertentu sebagai } \\
\text { imbalan pekerjaan yang sifatnya } \\
\text { rutin. }\end{array}$ & $\begin{array}{l}\text { 1. Adil (Fair/Equiable) } \\
\text { 2. Atraktif dan Kompetitif } \\
\text { 3. Tepat dan Mutakhir } \\
\text { 4. Mematuhi Ketentuan Undang- } \\
\text { Undang Peraturan Pemerintah } \\
\text { 5. Cukup/layak } \\
\text { (Ruky, 2016:35) }\end{array}$ \\
\hline $\begin{array}{l}\text { Kepemimpinan } \\
\left(\mathrm{X}_{3}\right)\end{array}$ & $\begin{array}{l}\text { Keterampilan dan kemampuan } \\
\text { seseorang untuk dapat } \\
\text { mempengaruhi personil lain agar } \\
\text { bekerja sesuai dengan tujuan } \\
\text { yang diharapkan. }\end{array}$ & $\begin{array}{l}\text { 1. Cara berkomunikasi } \\
\text { 2. Pemberian motivasi } \\
\text { 3. Kemampuan memimpin } \\
\text { 4. Pengambilan keputusan } \\
\text { 5. Kekuasaan positif } \\
\text { (Sunyoto, 2015:32) }\end{array}$ \\
\hline $\begin{array}{l}\text { Kinerja } \\
\text { karyawan (Y) }\end{array}$ & $\begin{array}{l}\text { Hasil kerja secara kualitas dan } \\
\text { kuantitas yang dicapai oleh } \\
\text { seseorang pegawai dalam } \\
\text { melaksanakan tugasnya sesuai } \\
\text { dengan tanggung jawab yang } \\
\text { diberikan kepadanya }\end{array}$ & $\begin{array}{l}\text { 1. Target } \\
\text { 2. Kualitas } \\
\text { 3. Waktu penyelesaian } \\
\text { 4. Taat asas } \\
\text { 5. Pengawasan } \\
\text { 6. Hubungan antar karyawan } \\
\text { (Edison, 2018:193) }\end{array}$ \\
\hline
\end{tabular}

\section{HASIL ANALISIS DAN PEMBAHASAN \\ Hasil Penelitian}

Uji Validitas

Hasil uji validitas untuk kuesioner Motivasi, Remunerasi, kepemimpinan dan Kinerja Personil Sat Sabhara Polres OKU Timur dijabarkan pada tabel 5.6 berikut ini:

Tabel 5.6

Hasil Uji Validitas Kuesioner Penelitian

\begin{tabular}{|c|c|c|c|}
\hline Butir Pernyataan & Nilai r hitung & $\begin{array}{c}\text { Nilai r table } \\
(\mathbf{N}=\mathbf{5 0} ; \boldsymbol{\alpha}=\mathbf{0 . 5 \%})\end{array}$ & Keterangan \\
\hline Motivasi (X1) & \multicolumn{3}{|l|}{} \\
\hline Item 1 & 0,557 & 0,279 & Valid \\
\hline Item 2 & 0,663 & 0,279 & Valid \\
\hline Item 3 & 0,394 & 0,279 & Valid \\
\hline Item 4 & 0,608 & 0,279 & Valid \\
\hline Item 5 & 0,573 & 0,279 & Valid \\
\hline Item 6 & 0,586 & 0,279 & Valid \\
\hline
\end{tabular}




\begin{tabular}{|c|c|c|c|}
\hline Item 7 & 0,577 & 0,279 & Valid \\
\hline Item 8 & 0,638 & 0,279 & Valid \\
\hline Item 9 & 0,622 & 0,279 & Valid \\
\hline \multicolumn{4}{|c|}{ Remunerasi (X2) } \\
\hline Item 1 & 0,556 & 0,279 & Valid \\
\hline Item 2 & 0,627 & 0,279 & Valid \\
\hline Item 3 & 0,504 & 0,279 & Valid \\
\hline Item 4 & 0,485 & 0,279 & Valid \\
\hline Item 5 & 0,644 & 0,279 & Valid \\
\hline Item 6 & 0,731 & 0,279 & Valid \\
\hline Item 7 & 0,586 & 0,279 & Valid \\
\hline Item 8 & 0,611 & 0,279 & Valid \\
\hline Item 9 & 0,661 & 0,279 & Valid \\
\hline Item 10 & 0,708 & 0,279 & Valid \\
\hline Item 11 & 0,651 & 0,279 & Valid \\
\hline Item 12 & 0,580 & 0,279 & Valid \\
\hline Item 13 & 0,657 & 0,279 & Valid \\
\hline Item 14 & 0,514 & 0,279 & Valid \\
\hline Item 15 & 0,620 & 0,279 & Valid \\
\hline
\end{tabular}

\section{Lanjutan Tabel 5.6}

\begin{tabular}{|c|c|c|c|}
\hline Butir Pernyataan & Nilai r hitung & $\begin{array}{c}\text { Nilai r table } \\
\text { (df=n-k-1;a=0.025) }\end{array}$ & Keterangan \\
\hline Kepemimpinan (X3) & \multicolumn{3}{|l|}{} \\
\hline Item 1 & 0,685 & 0,279 & Valid \\
\hline Item 2 & 0,717 & 0,279 & Valid \\
\hline Item 3 & 0,720 & 0,279 & Valid \\
\hline Item 4 & 0,626 & 0,279 & Valid \\
\hline Item 5 & 0,601 & 0,279 & Valid \\
\hline Item 6 & 0,783 & 0,279 & Valid \\
\hline Item 7 & 0,733 & 0,279 & Valid \\
\hline Item 8 & 0,680 & 0,279 & Valid \\
\hline Item 9 & 0,557 & 0,279 & Valid \\
\hline Item 10 & 0,759 & 0,279 & Valid \\
\hline Item 11 & 0,718 & 0,279 & Valid \\
\hline Item 12 & 0,778 & 0,279 & Valid \\
\hline Item 13 & 0,713 & 0,279 & Valid \\
\hline Item 14 & 0,764 & 0,279 & Valid \\
\hline Item 15 & 0,757 & 0,279 & Valid \\
\hline Kinerja (Y) & & & Valid \\
\hline Item 1 & 0,698 & 0,279 & Valid \\
\hline Item 2 & 0,621 & 0,279 & Valid \\
\hline Item 3 & 0,693 & 0,279 & Valid \\
\hline Item 4 & 0,700 & 0,279 & Valid \\
\hline Item 5 & 0,641 & 0,279 & Valid \\
\hline Item 6 & 0,573 & 0,279 & Valid \\
\hline Item 7 & 0,411 & 0,279 & Valid \\
\hline Item 8 & 0,638 & 0,279 & Valid \\
\hline Item 9 & 0,796 & 0,279 & \\
\hline Item 10 & 0,734 & 0,279 & 0,279 \\
\hline Item 11 & 0,532 & 0,279 & \\
\hline Item 12 & 0,478 & & \\
\hline
\end{tabular}

Sumber: Lampiran 5 
Pada tabel 5.6 terlihat bahwa nilai $\mathrm{r}$ hitung setiap butir pernyataan lebih besar dari $r$ tabel yaitu 0,279 sehingga hasil ini menunjukkan bahwa seluruh butir pernyataan pada variabel-variabel Motivasi, Remunerasi, Kepemimpinan dan Kinerja Personil adalah valid.

\section{Uji Reliabilitas}

Uji reliabilitas yang banyak digunakan yaitu metode Cronbach's Alpha. Metode
Cronbach's Alpha dengan nilai realibilitas instrumen $>0,6$ dapat disumpulkan bahwa instrumen reliabel dan jika nilai realibilitas instrumen $<0,6$ maka disimpulkan bahwa instrumen tidak reliabel (Priyatno, 2016:159). Hasil dari uji reliabilitas untuk kuesioner Motivasi, Remunerasi, kepemimpinan dan Kinerja Personil diperoleh sebagai berikut:

Tabel 5.7

Hasil Uji Reliabilitas Kuesioner Penelitian

\begin{tabular}{|c|c|c|}
\hline Variabel & Cronbach Alpha & Keterangan \\
\hline Motivasi & 0,854 & Reliabel \\
\hline Remunerasi & 0,906 & Reliabel \\
\hline Kepemimpinan & 0,943 & Reliabel \\
\hline Kinerja personil (Y) & 0,901 & Reliabel \\
\hline
\end{tabular}

Sumber: Lampiran 5

Berdasarkan tabel 5.7 didapatkan nilai reliabilitas butir pertanyaan pada kuesioner yang sedang diuji menunjukkan nilai masing-masing variabel yaitu Motivasi, Remunerasi, Kepemimpinan dan Kinerja
Personil memiliki nilai diatas 0,6 . Hal ini berarti indeks reliabilitas berada pada kategori tinggi. Dengan demikian bisa disimpulkan bahwa angket tersebut reliabel.

\section{Uji Asumsi Klasik}

\section{Uji Normalitas}

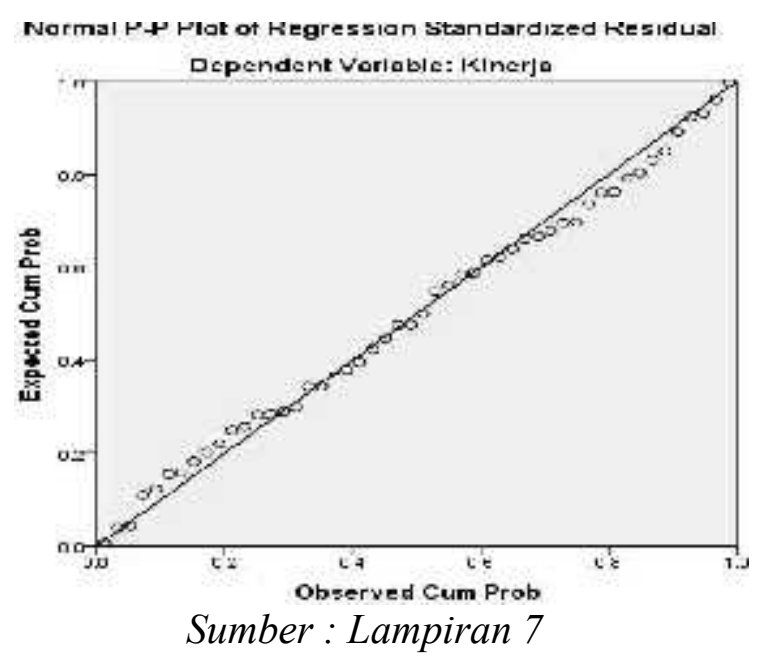

Gambar 5.6 Uji Normalitas 
Dari gambar 5.6 dapat dilihat bahwa grafik histogram didapatkan garis kurva normal, berarti data yang diteliti diatas berdistribusi normal. Demikian juga dari normal probabilty plot menunjukkan berdistribusi normal karena garis (titik- titik) mengikuti garis diagonal. Hal ini berarti residual data terdistribusi secara normal.

\section{Uji Multikolinearitas}

Tabel 5.8

\section{Hasil Uji Multikoliniearitas}

\begin{tabular}{|c|c|c|c|c|c|c|c|}
\hline \multicolumn{8}{|c|}{ Coefficients $^{\mathbf{a}}$} \\
\hline \multirow[t]{2}{*}{ Model } & \multicolumn{2}{|c|}{$\begin{array}{c}\text { Unstandardized } \\
\text { Coefficients }\end{array}$} & \multirow{2}{*}{$\begin{array}{c}\begin{array}{r}\text { Standardized } \\
\text { Coefficients }\end{array} \\
\text { Beta }\end{array}$} & \multirow[t]{2}{*}{$\mathrm{t}$} & \multirow[t]{2}{*}{ Sig. } & \multicolumn{2}{|c|}{ Collinearity Statistics } \\
\hline & B & Std. Error & & & & Tolerance & VIF \\
\hline (Constant) & -4.517 & 4.610 & & -.980 & .332 & & \\
\hline Motivasi & .320 & .106 & .254 & 3.021 & .004 & .690 & 1.449 \\
\hline Remunerasi & .519 & .095 & .550 & 5.477 & .000 & .485 & 2.062 \\
\hline Kepemimpinan & .146 & .068 & .214 & 2.143 & .037 & .490 & 2.040 \\
\hline
\end{tabular}

a. Dependent Variable: Kinerja

Sumber : Lampiran 5

Berdasarkan tabel 5.8 dapat dilihat bahwa nilai tolerance variabel $\mathrm{X} 1=0,690$, $\mathrm{X} 2=0,485$ dan $\mathrm{X} 3=0,490$, masing-masing nilai tolerance setiap variabel lebih besar dari 0,1. Kemudian didapatkan nilai VIF variabel $\mathrm{X}_{1}=1,449, \mathrm{X}_{2}=2,062$ dan $\mathrm{X} 3=$ 2,040 masing-masing nilai VIF setiap variabel lebih kecil dari 10. Maka dapat disimpulkan bahwa masingmasing variabel tidak terjadi multikolibearitas.

\section{Uji Heteroskedastisitas}

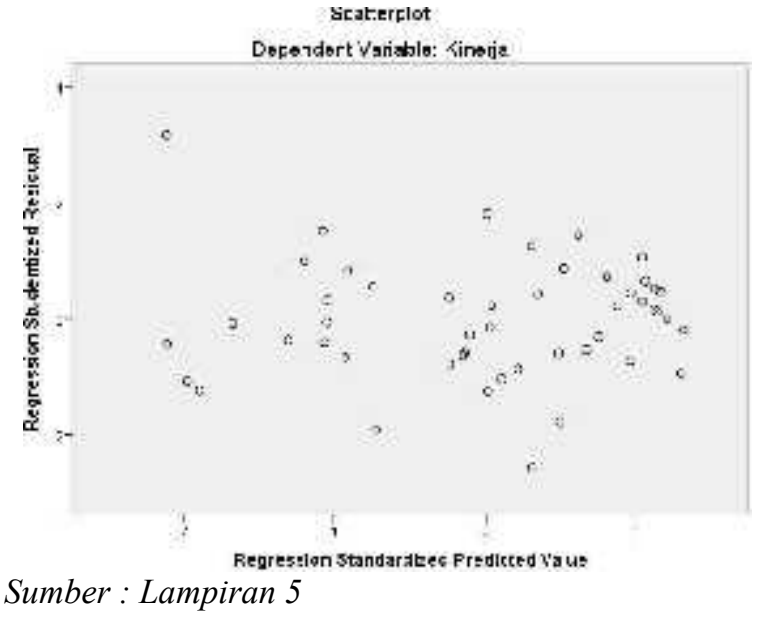

Gambar 5.7

Uji Heteroskedastisitas

Dari gambar 5.7 dapat dilihat bahwa sebaran titik-titik yang tidak membentuk pola tertentu namun tersebar di atas dan di bawah nol menunjukkan bahwa model regresi tidak mengalami masalah heteroskedastisitas. 


\section{Analisis Regresi Linear Berganda}

Tabel 5.9

Hasil Analisis Regresi Linear Berganda

\begin{tabular}{|c|c|c|c|c|}
\hline \multirow[t]{2}{*}{ Mode } & & \multicolumn{2}{|c|}{ Unstandardized Coefficients } & \multirow{2}{*}{$\begin{array}{c}\text { Standardized } \\
\text { Coefficients } \\
\text { Beta }\end{array}$} \\
\hline & & B & Std. Error & \\
\hline 1 & (Constant) & -2.212 & 4.870 & \\
\hline & Motivasi & .321 & .112 & .243 \\
\hline & Remunerasi & .482 & .089 & .551 \\
\hline & Kepemimpinan & .158 & .074 & .218 \\
\hline
\end{tabular}

a. Dependent Variable: Y

Sumber : Lampiran 5

Persamaan regresi linier berganda sebagai

berikut :

$Y=-2,212+(0,321) X 1+(0,482) X 2+$ $(\mathbf{0 , 1 5 8 ) X 3}$

Persamaan diatas dapat diinterprestasikan sebagai berikut:

1. Konstanta bernilai -2,212 yang berarti jika Motivasi (X1), Remunerasi (X2) dan Kepemimpinan (X3) nilainya nol atau tidak ada maka kinerja (Y) akan menurun sebesar 2,212 Satuan.

2. Koefisien regresi untuk Motivasi (X1) sebesar 0,321 menyatakan bahwa setiap kenaikan Motivasi (X1) sebesar 1 satuan, maka kinerja (Y) akan mengalami kenaikan sebesar $\mathbf{0 , 3 2 1}$ satuan dengan asumsi variabel Remunerasi (X2) dan Kepemimpinan
(X3) tetap.

3. Koefisien regresi untuk Remunerasi (X2) sebesar 0,482 menyatakan bahwa setiap kenaikan Remunerasi (X2) sebesar 1 satuan, maka kinerja (Y) akan mengalami kenaikan sebesar 0,482 satuan dengan asumsi variabel Motivasi (X1) dan dan Kepemimpinan (X3) tetap.

4. Koefisien regresi untuk Kepemimpinan (X3) sebesar $\mathbf{0 , 1 5 8}$ menyatakan bahwa setiap kenaikan kepemimpinan (X3) sebesar 1 satuan, maka kinerja (Y) akan mengalami kenaikan sebesar $\mathbf{0 , 1 5 8}$ satuan dengan asumsi variabel Motivasi (X1) dan dan Remunerasi (X2) tetap. 


\section{Pengujian Hipotesis Individual (Uji t)}

Tabel 5.10

Hasil Pengujian Secara Individual

(Uji t)

Coefficients $^{\mathrm{a}}$

\begin{tabular}{|c|c|c|c|c|c|c|}
\hline \multirow{2}{*}{\multicolumn{2}{|c|}{ Model }} & \multicolumn{2}{|c|}{ Unstandardized Coefficients } & \multirow{2}{*}{$\begin{array}{r}\text { Standardized } \\
\text { Coefficients }\end{array}$} & \multirow[t]{2}{*}{$\mathrm{t}$} & \multirow[t]{2}{*}{ Sig. } \\
\hline & & B & Std. Error & & & \\
\hline \multirow{4}{*}{1} & (Constant) & -2.212 & 4.870 & & -.454 & .652 \\
\hline & Motivasi & .321 & .112 & .243 & 2.860 & .006 \\
\hline & Remunerasi & .482 & .089 & .551 & 5.403 & .000 \\
\hline & Kepemimpinan & .158 & .074 & .218 & 2.147 & .037 \\
\hline
\end{tabular}

a. Dependent Variable: Kinerja

Sumber : Lampiran 5

Berdasarkan hasil pengolahan data dalam tabel 5.10 diperoleh :

a. Nilai t hitung Motivasi (X1) sebesar 2,860 dan $\mathrm{t}$ tabel $(\mathrm{df}=\mathrm{n}-\mathrm{k}-1=50-3$ 1=46:0,025), maka diperoleh $\mathrm{t}$ tabel : 2,01290), t hitung Motivasi (X1) 2,860 lebih kecil dari t tabel 2,01290 Jadi thitung $>$ ttabel dapat disimpulkan bahwa Ho ditolak dan $\mathrm{Ha}$ diterima, artinya Motivasi (X1) ada pengaruh secara signifikan terhadap Kinerja personil (Y).

b. Nilai t hitung Remunerasi (X2) sebesar 5,403 dan $\mathrm{t}$ tabel $(\mathrm{df}=\mathrm{n}-\mathrm{k}-1=50-3$ $1=46: 0,025)$, maka diperoleh $\mathrm{t}$ tabel : 2,01290), t hitung Remunerasi (X2) 5,403 lebih besar dari tabel 2,01290. Jadi thitung $>$ ttabel dapat disimpulkan Ho ditolak dan $\mathrm{Ha}$ diterima artinya Remunerasi (X2) ada pengaruh yang signifikan terhadap kinerja karyawan (Y).

c. Nilai $t$ hitung Kepemimpinan (X3)

sebesar 2,147 dan t tabel $(\mathrm{df}=\mathrm{n}-\mathrm{k}-1=50$ 3- 1=46:0,025), maka diperoleh $\mathrm{t}$ tabel : 2,01290), $\mathrm{t}$ hitung kepemimpinan (X2) 2,147 lebih besar dari $t$ tabel 2,01290. Jadi thitung $>$ ttabel dapat disimpulkan Ho ditolak dan $\mathrm{Ha}$ diterima artinya Kepemimpinan (X3) ada pengaruh yang signifikan terhadap kinerja karyawan (Y).

\section{Pengujian Hipotesis Secara Simultan (Uji F)}

Pengujian hipotesis secara Simultan (Uji F) digunakan untuk menguji pengaruh Motivasi (X1), Remunerasi (X2) dan Kepemimpinan (X3) secara bersama- sama terhadap kinerja Personil (Y). Uji F dilakukan dengan cara membandingkan nilai Fhitung dengan nilai Ftabel. Jika Fhitung $>$ Ftabel maka Ho ditolak dan Ha diterima, sedangkan jika Fhitung $<$ Ftabel maka Ho diterima dan Ha ditolak. Hasil perhitungan Uji $\mathrm{F}$ dapat dilihat pada tabel 5.11: 
Tabel 5.11

Hasil Pengujian Secara Simultan

(Uji F)

ANOVA $^{\mathrm{a}}$

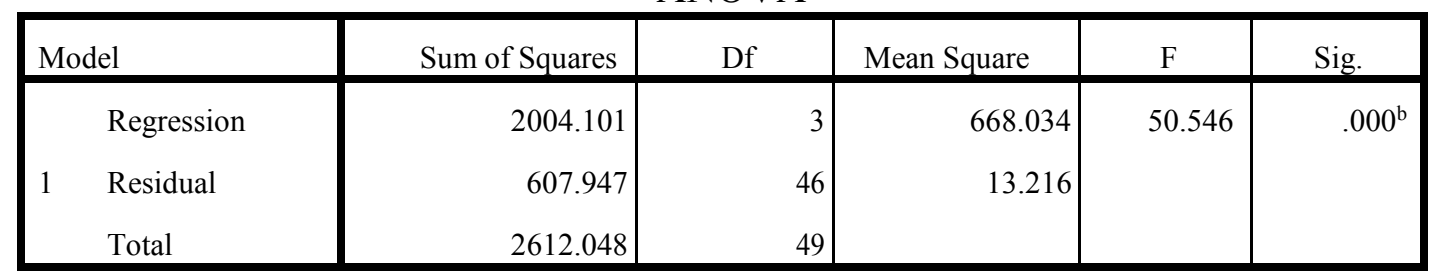

a. Dependent Variable: Kinerja

b. Predictors: (Constant), Kepemimpinan, Motivasi, Remunerasi

Sumber : data Primer yang diolah, 2020

Berdasarkan tabel 5.11 hasil pengolahan data diperoleh koefisien nilai Fhitung 50,546 lebih besar dari Ftabel 2,81 (df pembilang =3, dan df penyebut =n-k-1 = 50-3- 1= 46, maka diperoleh Ftabel $=2,81$ ). Hal ini menunjukan bahwa Fhitung $>$ Ftabel artinya Ho ditolak dan Ha diterima. Hal ini berarti bahwa hipotesis yang menyatakan secara simultan Motivasi (X1), Remunerasi (X2) dan Kepemimpinan (X3) mempunyai pengaruh terhadap Kinerja Personil (Y)

\section{Analisis Koefisien Determinasi}

Hasil analisis koefisien determinasi dapat dilihat pada tabel 5.12.

Tabel 5.12

Hasil Analisis Koefisien Determinasi

Model Summary

\begin{tabular}{|l|r|r|r|r|}
\hline Model & $\mathrm{R}$ & R Square & \multicolumn{1}{|c|}{$\begin{array}{c}\text { Adjusted R } \\
\text { Square }\end{array}$} & $\begin{array}{c}\text { Std. Error of the } \\
\text { Estimate }\end{array}$ \\
\hline 1 & $.876^{\mathrm{a}}$ & .767 & .752 & 3.63541 \\
\hline
\end{tabular}

a. Predictors: (Constant), Kepemimpinan, Motivasi, Remunerasi

Sumber : Data primer yang diolah, 2020

Berdasarkan Tabel 5.12 diperoleh angka Adjust R Square sebesar 0,752. Hal ini menunjukan bahwa sumbangan pengaruh variabel Motivasi $\left(\mathrm{X}_{1}\right)$, Remunerasi $\left(\mathrm{X}_{2}\right)$ dan Kepemimpinan $\left(\mathrm{X}_{3}\right)$ secara bersama-sama terhadap Kinerja personil (Y) sebesar 75,2\% sedangkan sisanya sebesar $24,8 \%$ dipengaruhi oleh variabel lain yang tidak dimasukkan dalam model penelitian ini seperti disiplin kerja, lingkungan kerja, dan hubungan komunikasi organisasi yang diduga besar pengaruhnya terhadap kinerja personil.

\section{Pembahasan}

Berdasarkan uji hipotesis secara parsial menunjukkan bahwa motivasi memiliki pengaruh yang positif dan signifikan terhadap kinerja personil Sat Sabhara Polres OKU Timur. Hal ini ditunjukkan dengan nilai koefisien t hitung Motivasi $\left(\mathrm{X}_{1}\right)$ lebih besar dari pada $t$ tabel yaitu 2,860 $>2,01290$ dan taraf signifikan $0,006<0,05$ maka Ho ditolak dan Ha diterima artinya ada pengaruh Motivasi $\left(\mathrm{X}_{1}\right)$ terhadap Kinerja Personil (Y). Maksudnya motivasi merupakan variabel penting, dimana motivasi perlu mendapat perhatian yang besar 
bagi instansi dalam peningkatan kinerja personilnya. Semakin tinggi variabel motivasi maka semakin baik kinerja karyawan. Apabila motivasi baik kinerja juga akan baik hal ini dipengaruhi oleh kebutuhan untuk berprestasi, kebutuhan untuk berafiliasi, dan kebutuhan untuk kekuasaan.

Hasil penelitian ini sesuai dengan teori motivasi merupakan kondisi atau energi yang menggerakkan diri karyawan yang terarah atau tertuju untuk mencapai tujuan organisasi perusahaan. Sikap mental karyawan yang pro dan positif terhadap situasi kerja itulah yang memperkuat motivasi kerjanya untuk mencapai kinerja maksimal (Mangkunegara, 2019:61). Hasil penelitian tentang pengaruh motivasi terhadap kinerja juga sejalan dengan hasil penelitian sebelumnya yaitu dari Hidayat dan Taufiq (2012) meneliti tentang pengaruh lingkungan kerja, disiplin kerja, motivasi kerja secara bersama-sama terhadap kinerja kinerja karyawan perusahaan daerah air minum (PDAM) Kabupaten Lumajang. Penelitian ini menggunakan alat regresi linear berganda. Hasil penelitian diketahui bahwa ada pengaruh yang signifikan dari variabel lingkungan kerja, disiplin kerja dan motivasi kerja secara simultan berpengaruh terhadap kinerja karyawan. Lingkungan kerja dan disiplin kerja serta motivasi kerja berpengaruh signifikan secara parsial terhadap kinerja namun disiplin kerja mempunyai pengaruh yang dominan terhadap kinerja karyawan PDAM Kabupaten Lumajang.

\section{Pengaruh Remunerasi terhadap Kinerja Personil Sat Sabhara Polres OKU Timur}

Berdasarkan uji hipotesis parsial menunjukkan bahwa Remunerasi memiliki pengaruh yang positif dan signifikan terhadap kinerja personil Sat Sabhara Polres OKU Timur. Hal ini ditunjukkan dengan nilai t hitung $5,403>\mathrm{t}$ tabel 2,01290 dan taraf signifikan $0,000<0,05$ sehingga Ho ditolak dan $\mathrm{Ha}$ diterima artinya ada pengaruh yang signifikan Remunerasi $\left(\mathrm{X}_{2}\right)$ terhadap Kinerja personil $(\mathrm{Y})$. Maksudnya apabila remunerasi tidak berjalan dengan baik maka kinerja personil tidak akan berjalan dengan baik dan tidak sesuai dengan tujuan yang diharapkan, sebaliknya apabila remunerasi berjalan dengan maksimal maka kinerja personil Sat Sabhara Polres OKU Timur akan berjalan dengan baik sesuai dengan tujuan yang diharapkan. Apabila remunerasi baik kinerja juga akan baik hal ini dipengaruhi oleh pembeian remunerasi yang adil, atraktif dan kompetitif, tepat dan mutakhir, mematuhi ketentuan undang-undang peraturan pemerintah, dan cukup/layak.

\section{Pengaruh Kepemimpinan terhadap Kinerja Personil Sat Sabhara Polres OKU Timur}

Berdasarkan uji hipotesis parsial menunjukkan bahwa kepemimpinan memiliki pengaruh yang positif dan signifikan terhadap kinerja Personil Sat Sabhara Polres OKU Timur. Hal ini ditunjukkan dengan nilai t hitung $2,147>\mathrm{t}$ tabel 2,01290 dan taraf signifikan $0,037<0,05$ sehingga Ho ditolak dan $\mathrm{Ha}$ diterima artinya ada pengaruh yang signifikan Kepemimpinan $\left(\mathrm{X}_{3}\right)$ terhadap Kinerja personil (Y). Dalam penelitian ini didapatkan hasil bahwa kepemimpinan berpengaruh terhadap kinerja personil Sat Sabhara Polres OKU Timur. Hal ini disebabkan karena kepemimpinan yang ideal bagi personil Sat Sabhara Polres OKU Timur adalah para pemimpin dapat membangun cara berkomunikasi, pemberian motivasi, kemampuan memimpin, pengambilan keputusan dan kekuasaan positif di antara personil sehingga personil dapat meningkatkan kinerjanya.

\section{Pengaruh Motivasi, Remunerasi dan Kepemimpinan terhadap Kinerja Personil Sat Sabhara Polres OKU Timur}

Berdasarkan hasil uji hipotesis simultan menunjukkan bahwa Motivasi $\left(\mathrm{X}_{1}\right)$, Remunerasi $\left(\mathrm{X}_{2}\right)$ dan Kepemimpinan $\left(\mathrm{X}_{3}\right)$ mempunyai pengaruh terhadap Kinerja Personil (Y) pada Sat Sabhara Polres OKU Timur. Hal ini diketahui dari hasil pengolahan data diperoleh koefisien nilai $F_{\text {hitung }}$ 50,546 lebih besar dari $\mathrm{F}_{\text {tabel }} 2,81$ (df pembilang $=3$, dan $\mathrm{df}$ penyebut $=\mathrm{n}-\mathrm{k}-1=50-3-1=46$, maka diperoleh 
$\left.\mathrm{F}_{\text {tabel }}=2,81\right)$. Hal ini menunjukan bahwa $\mathrm{F}_{\text {hitung }}$

$>F_{\text {tabel }}$ artinya Ho ditolak dan Ha diterima.

Nilai koefisien Adjust R Square sebesar 0,752. Hal ini menunjukan bahwa sumbangan pengaruh variabel Motivasi $\left(\mathrm{X}_{1}\right)$, Remunerasi $\left(\mathrm{X}_{2}\right)$ dan Kepemimpinan $\left(\mathrm{X}_{3}\right)$ mempunyai pengaruh secara bersama-sama terhadap Kinerja personil (Y) pada Sat Sabhara Polres OKU Timur sebesar $75,2 \%$ sedangkan sisanya sebesar $24,8 \%$ dipengaruhi oleh variabel lain yang tidak dimasukkan dalam model penelitian ini seperti disiplin kerja, lingkungan kerja, dan hubungan komunikasi organisasi yang diduga besar pengaruhnya terhadap kinerja personil.

\section{KESIMPULAN DAN SARAN \\ Kesimpulan}

Berdasarkan hasil analisis dan pembahasan pada bab sebelumnya maka dapat disimpulkan sebagai berikut:

a. Secara parsial Motivasi $\left(\mathrm{X}_{1}\right)$ berpengaruh terhadap Kinerja Personil (Y) dengan nilai koefisien $t$ hitung Motivasi $\left(\mathrm{X}_{1}\right)$ lebih besar dari pada $\mathrm{t}$ tabel yaitu 2,860>2,01290 dan taraf signifikan $0,006<0,05$ maka Ho ditolak dan Ha diterima artinya ada pengaruh Motivasi $\left(\mathrm{X}_{1}\right)$ terhadap Kinerja Personil (Y) pada Sat Sabhara Polres OKU Timur. Adapun, untuk Remunerasi $\left(\mathrm{X}_{2}\right)$ secara parsial berpengaruh terhadap Kinerja Personil (Y) dengan nilai $t$ hitung 5,403 $>$ t tabel 2,01290 dan taraf signifikan $0,000<0,05$ sehingga Ho ditolak dan $\mathrm{Ha}$ diterima artinya ada pengaruh yang signifikan Remunerasi $\left(\mathrm{X}_{2}\right)$ terhadap Kinerja personil $(\mathrm{Y})$ pada Sat Sabhara Polres OKU Timur. Selain itu, Kepemimpinan $\left(\mathrm{X}_{3}\right)$ juga secara parsial berpengaruh terhadap Kinerja Personil (Y) dengan nilai t hitung 2,147 $>\mathrm{t}$ tabel 2,01290 dan taraf signifikan $0,037<0,05$ sehingga Ho ditolak dan Ha diterima artinya ada pengaruh yang signifikan Kepemimpinan $\left(\mathrm{X}_{3}\right)$ terhadap Kinerja personil $(\mathrm{Y})$ pada Sat Sabhara Polres OKU Timur. Hal ini tentu saja secara simultan bahwa Motivasi $\left(\mathrm{X}_{1}\right)$, Remunerasi $\left(\mathrm{X}_{2}\right)$ dan Kepemimpinan $\left(\mathrm{X}_{3}\right)$ berpengaruh terhadap Kinerja personil (Y) pada Sat Sabhara Polres OKU Timur

b. Besarnya koefisien determinasi (Adjusted R Square) Motivasi ( $\mathrm{X}_{1}$, Remunerasi $\left(\mathrm{X}_{2}\right)$ dan Kepemimpinan $\left(\mathrm{X}_{3}\right)$ berpengaruh sebesar 75,2\% terhadap Kinerja Personil (Y) pada Sat Sabhara Polres OKU Timur sedangkan sisanya sebesar $24,8 \%$ dipengaruhi oleh variabel lain.

c. Pada penelitian ini, variabel yang mempunyai pengaruh lebih signifikan terhadap Kinerja Personil (Y) berdasarkan hasil uji reliabilitas didapat nilai cronbach alfa Motivasi $\left(\mathrm{X}_{1}\right)$ sebesar 0,854, nilai cronbach alfa Remunerasi $\left(\mathrm{X}_{2}\right)$ sebesar 0,906, dan nilai cronbach alfa Kepemimpinan (X $\mathrm{X}_{3}$ sebesar 0,943. Hal ini menunjukkan bahwa nilai cronbach alfa pada variabel Kepemimpinan $\left(\mathrm{X}_{3}\right)$ lebih tinggi dari variabel Motivasi $\left(\mathrm{X}_{1}\right)$ dan Remunerasi $\left(\mathrm{X}_{2}\right)$ artinya variabel Kepemimpinan $\left(\mathrm{X}_{3}\right)$ berpengaruh lebih signifikan terhadap Kinerja Personil (Y) Pada Sat Sabhara Polres OKU Timur.

\section{Saran}

Berdasarkan kesimpulan sebelumnya, maka peneliti menyarankan sebagai berikut:

Diharapkan kepada pimpinan dapat meningkatkan motivasi kerja pada personil yang menunda pekerjaan, memberi dorongan kepada semua Personil Sat sabhara Polres OKU Timur agar tidak menumpuk pekerjaan dan adanya target volume kerja, sehingga semua pekerjaan dapat diselesaikan tepat waktu. Bagi pimpinan agar memberikan motivasi, dukungan serta semangat kepada personilnya sehingga personil 
Satsabhara Polres OKU Timur bersedia memberikan kinerjanya yang terbaik bagi Instansi.

a. Pemberian remunerasi disarankan agar sesuai dengan posisi pekerjaan, tepat sasaran sesuai kebutuhan pada bidangnya.

b. Berkaitan dengan kepemimpinan secara umum, perhatian yang besar terhadap kebutuhan personil secara individu perlu dipertimbangan oleh setiap pemimpin. Pemimpin hendaknya paham betul terhadap kebutuhan apa yang belum dapat dipenuhi, dan masih menjadi kendala dalam pekerjaannya, dan selalu berusaha untuk memberikan pemenuhan atas kebutuhan bawahannya.

Bagi peneliti berikutnya diharap dapat menambah variabel lain seperti disiplin kerja, lingkungan kerja, dan hubungan komunikasi organisasi yang diduga besar pengaruhnya terhadap kinerja personil Sat Sabhara Polres OKU Timur.

\section{DAFTAR PUSTAKA}

Arifudin, Zainal. 2017. Pengaruh Kepemimpinanan dan Disiplin Kerja terhadap Kinerja Karyawan PD BPR Bank Daerah Kabupaten Kediri. Jurnal Simki- Economic Universitas Nusantara PGRI Kediri Vol. 01 No. 04.

Fitriyana, Pangestika dan Anthon Rustono. 2016. Pengaruh Sistem Remunerasi Terhadap Kinerja Pegawai Dinas Bina Marga dan Pengairan Kota Bandung. Jurnal Fakultas Ekonomi dan Bisnis Universitas Telkom Vol. 3 No. 2.

Hasibuan, Malayu, 2017. Manajemen Sumber Daya Manusia. Bandung: Remaja Rosdakarya.

Hidayat, Zainul dan Muchammad Taufiq. 2012. Pengaruh Lingkungan Kerja, Disiplin Kerja, dan Motivasi Kerja terhadap Kinerja Karyawan

Perusahaan Daerah Air Minum (PDAM) Kabupaten Lumajang. Jurnal Wiga Vol. 02 No. 01.

Kasmir, 2016. Manajemen Sumber Daya Manusia Teori Dan Praktik. Jakarta: Raja Grafindo Persada.

Mangkunegara, Anwar. 2017. Sumber Daya Manusia perusahaan. Bandung: Remaja Rosdakarya.

Mangkunegara, Anwar. 2019. Evaluasi Kinerja Sumber Daya Manusia. Bandung: Refika Aditama.

Peraturan Kepala Kepolisian Negara Republik Indonesia Nomor 23, Tahun 2010 tentang Susunan Organisasi dan Tata Kerja Pada Tingkat Kepolisian Resort dan Kepolisian Sektor. 2010. Peraturan Kepala Kepolisian Negara Republik Indonesia, Jakarta.

Peraturan Presiden Republik Indonesia Nomor 103, Tahun 2018 tentang Tunjangan Kinerja Pegawai Di Lingkungan Kepolisian Negara Republik Indonesia. 2018. Lembaga Negara Republik Indonesia, Jakarta.

Priyatno, Duwi, 2016. Belajar Analisis Data dan Cara Pengolahannya dengan SPSS Prakti dan Mudah di Pahami Untuk Tingkat Pemula dan Menengah. Yogyakarta:.Gava Media. Siswanto, 2007. Pengantar Manajemen. Jakarta: Bumi Aksara.

Sugiyono, 2016. Metode Penelitian Manajemen Pendekatan Kuantitatif, Kualitatif, Kombinasi (Mixed Methods), Penelitian Tindakan (Action Research) Dan Penelitian Evaluasi. Bandung: Alfabeta. 